\title{
Seasonal Variations of Polyphenols Content, Sun Protection Factor and Antioxidant Activity of Two Lamiaceae Species
}

\author{
Juliana de Medeiros Gomes, Márcio Vinícius Cahino Terto, Sócrates Golzio do Santos, Marcelo Sobral da Silva and \\ Josean Fechine Tavares *(1)
}

check for updates

Citation: de Medeiros Gomes, J.; Cahino Terto, M.V.; Golzio do Santos, S.; Sobral da Silva, M.; Fechine Tavares, J. Seasonal Variations of Polyphenols Content, Sun Protection Factor and Antioxidant Activity of Two Lamiaceae Species. Pharmaceutics 2021, 13, 110. https://doi.org/ 10.3390/pharmaceutics13010110

Received: 5 December 2020 Accepted: 13 January 2021 Published: 16 January 2021

Publisher's Note: MDPI stays neutral with regard to jurisdictional clai$\mathrm{ms}$ in published maps and institutional affiliations.

Copyright: () 2021 by the authors. Licensee MDPI, Basel, Switzerland. This article is an open access article distributed under the terms and conditions of the Creative Commons Attribution (CC BY) license (https:// creativecommons.org/licenses/by/ $4.0 /)$.
Laboratório Multiusuário de Caracterização e Análise, Universidade Federal da Paraíba, João Pessoa, PB 58051-900, Brazil; juliana@ltf.ufpb.br (J.d.M.G.); cahino@ltf.ufpb.br (M.V.C.T.); socratesgolzio@ltf.ufpb.br (S.G.d.S.); marcelosobral.ufpb@gmail.com (M.S.d.S.)

* Correspondence: josean@ltf.ufpb.br; Tel.: +55-83-98802-7809

Abstract: Secondary metabolite production by plants is influenced by external environmental factors that can change depending on the seasons, which makes it important to know how the plant, through its metabolism, is able to adapt to these variations. Mentha $x$ villosa and Plectranthus amboinicus present in their chemical composition polyphenols, and through previous studies, it has been seen that these two species present promising in vitro photoprotective activity. The aim of this study was to evaluate seasonal alterations in photoprotective and antioxidant activities and the influence of factors such as precipitation levels and sun radiation incidence. Thus, polyphenol quantification, cromatographics (HPLC-DAD) and multivariate (PCA) analyses of extracts of the two species through twelve months were done. It was observed that the best months for photoprotective and antioxidant activities were September for M. villosa and July for P. amboinicus (SPF =14.79). It was possible to conclude that solar radiation more clearly influences the production of phenolics and the increase of SPF in $M$. villosa, in addition to favoring the antioxidant activity of the two species, while precipitation seems to have no influence.

Keywords: photoprotection; M. villosa; P. amboinicus; ultraviolet radiation; PCA; seasonality

\section{Introduction}

Seasonal variations of secondary metabolites produced by plants, both qualitatively and quantitatively, can occur throughout the year in response to modifications in plant environmental conditions, including climatic $[1,2]$. This variation can also modify the biological activity that plant extracts have, since samples of the same plant collected in different months will present, or not, some compounds, as well as their concentration can also be different, thus, the extract can even present different pharmacological properties throughout the year $[3,4]$.

It is known that an increase of UVB radiation incidence and a decrease of precipitation can cause an increase in the production of free radicals, causing cellular damage that forces the plant to respond to this stimulus, altering morphological characteristics until the content of metabolites produced change, i.e., the increase of polyphenols [5]. Therefore, by evaluating environmental factors such as temperature, water availability, solar radiation incidence, among others, we can better understand the metabolic alterations happening in plants [6-8].

Mentha $x$ villosa Hudson and Plectranthus amboinicus (Lour.) Spreng are two species from the Lamiaceae Family that, in Brazil, that are popularly called "hortelã da folha miúda" and "hortelã da folha grossa", respectively. They are used in folk medicine mainly as antimicrobials, but M. $x$ villosa is also used in the form of infusion or decoction of its leaves to treat stomach problems and menstrual cramps, in addition to being used as a sedative [9] and an antiparasitic [10]. Scientifically, its endothelium-dependent hypotensive and vasorelaxant 
effects have been demonstrated [11], as well as its antimicrobial, antinociceptive [12], antitumor [13], anti-inflammatory [14] and antioxidant activities [15,16]. P. amboinicus is used for the treatment of colds, coughs, asthma, and diseases of the respiratory tract in general, as well as to treat headaches, fever, skin diseases, and gastrointestinal disorders [17-19]. Thus, because it is a well-known species and used by the population, many studies on its effects already exist and demonstrate its antimicrobial and antiviral activities in vitro [20,21], activity against respiratory and gastrointestinal disorders, anticonvulsant, antitumor [22,23], analgesic, anti-inflammatory, and antioxidant activities [24,25]. These two species are also used in culinary as flavorings and in the preparation of some foods $[17,26]$.

Many of the biological activities presented by M. villosa and P. amboinicus are due to the presence of essential oils that are widely studied and have monoterpenes and sesquiterpenes in their composition $[17,27]$. However, its nonvolatile extracts also have a large amount of biologically interesting compounds, such as phenolic compounds. In M. villosa, several phenolic acids have been identified, such as rosmarinic acid, quinic acid, and chlorogenic acid, as well as several flavonoids, such as luteolin and apigenin derivatives, hesperidin, kaempferol-3-O-glucuronide, eriocitrin and chrysoeriol-7-O-rutinoside [28]. In P. amboinicus, many polyphenols have also been identified, such as caffeic acid, gallic acid, rosmarinic acid, crisimaritin, luteolin, and apigenin derivatives, p-cumaric acid, taxolifin, among others [29].

Therefore, these species present in their chemical composition an interesting quantity of phenolic compounds, that are a secondary metabolite class mainly known because of their anti-inflammatory, antioxidant and photoprotective properties [30-32]. Their antioxidant properties are closely linked to their stable chemical structures, making them capable of neutralizing reactive oxygen species (ROS), inhibiting lipid peroxidation, and even preventing the production of free radicals [33].

A relevant property attributed to this metabolite class is the solar protection activity, since they are capable of filtering the incident ultraviolet radiation. Therefore, when UVB and UVA rays intensity is high, plants can be stimulated to produce phenolic compounds so they can absorb or disperse solar energy and make it harder to damage plant tissues $[34,35]$.

M. villosa and P. amboinicus have rosmarinic acid (RA) as the majority compound in their ethanolic extracts. Studies related to photoprotective activity of this acid have showed a favorable future for this metabolite, since its photoprotective capacity has been observed, besides having good antioxidant activity and contributing to lipid peroxidation inhibition [36-38], which places it in a relevant position in the development of new sunscreens.

Thus, based on the extensive literature demonstrating M. $x$ villosa and P. amboinicus therapeutic aspects, these two species deserve attention, mainly in areas where they are not well explored, such as in photoprotection and seasonality of nonvolatile extracts, since plants employ many mechanisms to adapt themselves to its environmental conditions in order to regulate its metabolism [39] and it can directly impact in secondary metabolites production. Therefore, understanding the annual variations of secondary metabolites of these two species can help us to better use them in terms of pharmaceutical product development. A previous study by Terto et al. [40], as well as unpublished data [41], showed that these two species have promising photoprotective activity in vitro since they presented a sun protection factor (SPF) of around 13. Thus, we evaluated the seasonal variations that occurred in M. x villosa and P. amboinicus, by monitoring the quantitative production of polyphenols, flavonoids, and rosmarinic acid month by month, the role of solar radiation, and precipitation in the production of these metabolites and their implications for the SPF and antioxidant activity of these extracts.

\section{Materials and Methods}

\subsection{Plant Material}

Aerial parts of Mentha x villosa Hudson and Plectranthus amboinicus (Lour.) Spreng., Lamiaceae, were collected at 8 am on the 20th of every month, from January to December 2019, where they were cultivated at the Federal University of Paraiba, Institute of Pharma- 
ceuticals Research (coordinates $7^{\circ} 8^{\prime} 29.875^{\prime \prime}$ S $/ 34^{\circ} 50^{\prime} 48.757^{\prime \prime}$ W), Campus I, João Pessoa, PB. A specimen of $M$. villosa was placed in the Herbário Prisco Bezerra, from the Federal University of Ceará, Fortaleza-CE, under n 14.996. This plant is registered at the SISGEN (National System of Genetic Heritage Management and Associated Traditional Knowledge) platform under reference number A3BA60D. A specimen of P. amboinicus species is deposited at Lauro Pires Xavier Herbarium (JPB/UFPB) under number identification JPB0047239 and its register at SISGEN is under reference number AAB0FA6.

\subsection{Preparation of Crude Ethanol Extracts}

Fresh aerial parts (500 g) of M. villosa and P. amboinicus were crushed and submitted to maceration in $96 \%$ ethanol for three consecutive days; this process was repeated three times. 41 of ethanol was used in the maceration process of $M$. villosa and 31 of ethanol for P. amboinicus. After maceration, extracted solutions were concentrated using rotary evaporator equipment at $40{ }^{\circ} \mathrm{C}$ to obtain the crude ethanolic extracts (CEE) of the two species, weighing approximately $11.5 \mathrm{~g}$ for $M$. villosa and $12.37 \mathrm{~g}$ for P. amboinicus. The maceration process was repeated every month of 2019 right after aerial parts harvest, resulting in 12 M. $x$ villosa ethanolic extracts and 12 P. amboinicus ethanolic extratcs. All of these extracts were used in every test made.

\subsection{Reagents and Equipment}

Solvents used were HPLC-grade methanol (Tedia ${ }^{\circledR}$, Rio de Janeiro, Brazil), formic acid (J. T. Baker ${ }^{\circledR}$, Aparecida de Goiânia, Brazil), acetic acid (J. T. Baker ${ }^{\circledR}$, Aparecida de Goiânia, Brazil), phosphoric acid (Proquimios ${ }^{\circledR}$, Rio de Janeiro, Brazil), and type I water obtained by a purification system (Milli-Q-Millipore ${ }^{\circledR}$ ), besides absolute ethanol (Neon ${ }^{\circledR}$, Suzano, Brazil), Polawax ${ }^{\circledR}$ cream (João Pessoa, Brazil), Folin-Ciocalteu reagent, 1-1-diphenyl-2picrylhydrazyl (DPPH) (Sigma-Aldrich, São Paulo, Brazil), aluminum chloride $\left(\mathrm{AlCl}_{3}\right)$ and Rosmarinic acid (RA) obtained from Sigma Aldrich ${ }^{\circledR}$, São Paulo, Brazil, with $96 \%$ of purity.

The used equipments were a UV-visible spectrophotometer (UV-2550, Shimadzu ${ }^{\circledR}$, Barueri, Brazil) and an HPLC system from Shimadzu ${ }^{\circledR}$ (prominence) equipped with LC20AT quaternary solvent pumping module, SIL-20A HT auto-injector, DGU-20A5R degassing system, CTO-20A column oven, detector SPD-M20A diode array and CBM-20A controller. The column used was Kromasil ${ }^{\circledR} \mathrm{C} 18(250 \mathrm{~mm} \times 4.6 \mathrm{~mm}$ a.i. filled with $5 \mu \mathrm{m}$ particles) (Sigma Aldrich ${ }^{\circledR}$, São Paulo, Brazil), with SecurityGuard Gemini ${ }^{\circledR}$ C18 pre-column $\left(4 \mathrm{~mm} \times 3.0 \mathrm{~mm}\right.$ a.i. filled with $5 \mu \mathrm{m}$ particles). The LC Solution ${ }^{\circledR}$ software (Shimadzu ${ }^{\circledR}$, Barueri, Brazil) was used for equipment control, data acquisition, and analysis.

\subsection{HPLC Analytical Chromatographic Methods}

The method used for quantification of RA in M. villosa begins at $38 \%$ of solvent B, reaching $42 \%$ in $5 \mathrm{~min}$ and remains at this concentration until $9 \mathrm{~min}$. From 9 to $12 \mathrm{~min}$, the gradient is altered from 42 to $45 \%$ of solvent B and it reaches $50 \%$ in 15 min. From 15 to $17 \mathrm{~min}$, the gradient returns to $45 \%$, and it remains unchanged until $20 \mathrm{~min}$, when it returns to the initial condition at $38 \%$ of mobile phase $B$, and the run stops at 24 min at this concentration. The flow rate used was $1 \mathrm{~mL} / \mathrm{min}$, oven temperature at $26{ }^{\circ} \mathrm{C}$, the injection volume of $20 \mu \mathrm{L}$, the detection was performed at $330 \mathrm{~nm}$ by a diode array UV (DAD). In addition, extract and standard samples were made in triplicate and filtered with the diluent solution at a concentration of 50\%: $50 \% \mathrm{MeOH}$ : acidified water $\left(0.1 \%\right.$ of $\left.\mathrm{H}_{3} \mathrm{PO}_{4}\right)$.

For extract samples of $P$. amboinicus, a diluent solution used was $\mathrm{MeOH}$ :acidified water $(0.1 \%$ of formic acid) $1: 1$, the run starts at $50 \%$ of solvent $B$ and reaches $60 \%$ in $20 \mathrm{~min}$, returning to $50 \%$ in $21 \mathrm{~min}$ and remaining at this concentration until the end, at $26 \mathrm{~min}$. In this case, the flow rate used was $0.6 \mathrm{~mL} / \mathrm{min}$ [40].

\subsection{Solar Radiation and Precipitation Treatments}

The exposure consisted of submitting plants to naturally occurring solar radiation and precipitation during 2019 at their harvest place at the Institute of Pharmaceuticals 
Research-UFPB and collecting adult plants to observe changes in the content of investigated compounds among each month of harvest. Solar radiation incidence and precipitation data were collected on the website (https: / / portal.inmet.gov.br/) of the National Meteorologic Institute of Brazil (INMET).

\subsection{Total Polyphenol Content Determination}

In this assay [42], $120 \mu \mathrm{L}$ of samples (from the two plants, for each month) at a concentration of $1 \mathrm{mg} / \mathrm{mL}$ were treated with $500 \mu \mathrm{L}$ of Folin-Ciocalteu $(10 \%)$ reagent and gallic acid was used as standard. Time reaction was $8 \mathrm{~min}$, and at this moment, the reaction was maintained at rest. Later, $400 \mu \mathrm{L}$ of sodium carbonate $(7.5 \%)$ was added to neutralize the mixture. Then, triplicate samples were kept at room temperature, in the dark for $120 \mathrm{~min}$. Meanwhile, they were transferred to 96 well plates for later reading on a UV-visible spectrophotometer (UV-2550, Shimadzu) at $765 \mathrm{~nm}$.

Linear regression was used to calculate the total phenolic content of samples, it was made through gallic acid calibration curve $(25,50,75,100,150$ and $200 \mu \mathrm{g} / \mathrm{mL})$, and results were expressed as $\mathrm{mg} \mathrm{GAE/g}$ of the sample.

\subsection{Rosmarinic Acid Quantification}

RA quantification was made through the construction of a calibration curve using the standard concentrations of 5.6, 11.25, 22.5, 45 and $90 \mu \mathrm{g} / \mathrm{mL}$ for extracts of both species. Samples of each month were prepared in triplicate, at a concentration of $1 \mathrm{mg} / \mathrm{mL}$ and were injected in HPLC according adequate analytical method described.

\subsection{Flavonoids Total Content Determination}

Flavonoids content was evaluated by the spectrophotometric method proposed by Schmidt and Ortega, [43] with adaptations, using aluminum chloride $\left(\mathrm{AlCl}_{3}\right)$ as a reagent. Thus, $0.1 \mathrm{~mL}$ of $\mathrm{AlCl}_{3}(2.5 \%)$ was added to $0.1 \mathrm{~mL}$ of samples $(1 \mathrm{mg} / \mathrm{mL})$ in 96 well plates. The mixture was kept away from light for $30 \mathrm{~min}$, and later, absorbance was measured at $410 \mathrm{~nm}$, using a spectrophotometer UV-Visivel (UV-2550, Shimadzu) [44]. The assay was made in triplicate and flavonoids total content was calculated through a linear regression equation obtained from the quercetin calibration curve (5; 25; 50; 100 and $200 \mu \mathrm{g} / \mathrm{mL}$ ). Results were expressed as mg of quercetin/g of sample.

\subsection{Determination of Antioxidant Activity}

DPPH method was applied for this assay [45], using methanol as a solvent. Thus, in 96 well plates, DPPH solution at $0.3 \mathrm{mM}(100 \mu \mathrm{L})$ was added to $100 \mu \mathrm{L}$ of different concentrations of extracts of both plants studied (usually 10, 20,40, 80, and $160 \mu \mathrm{g} / \mathrm{mL}$ were used, but in certain samples, it was also necessary to use $320 \mu \mathrm{g} / \mathrm{mL}$ ). This reaction remained at rest and away from light for $30 \mathrm{~min}$ and subsequently, the reading was done on a spectrophotometer UV-Visivel (UV-2550, Shimadzu) at $518 \mathrm{~nm}$. This assay was performed on samples of all months in triplicate and, free radical scavenging activity (SA) of each concentration used was calculated by the following Equation (1). After calculating SA, calibration curves were done and results were expressed as $\mathrm{CE}_{50}$.

$$
\text { SA }(\%)=\left(A_{\text {negative control }}-\mathrm{A}_{\text {sample }}\right) / A_{\text {negative control }} \times 100
$$

Equation (1) Free radical scavenging activity formula. where,

SA $(\%)=$ percentage of free radical scavenging activity

$\mathrm{A}_{\text {negative control }}=$ negative control absorbance

$\mathrm{A}_{\text {sample }}=$ sample absorbance 


\subsection{In Vitro Determination of Sun Protection Factor (SPF)}

SPF was determined according to an in vitro method [46], known for being practical and presenting a good correlation with in vivo methodologies. Thus, formulations were prepared using polawax ${ }^{\circledR}$ cream as a cosmetic base and extracted samples from all months harvested of both species, separately, were incorporated at a concentration of $10 \%$. For spectrophotometric analyses, liquid samples of each formulation were prepared at $0.2 \mathrm{mg} / \mathrm{mL}$, using absolute ethanol as solvent. Subsequently, a scan was made between the wavelengths of 200-400 nm using a spectrophotometer UV-Vis, UV-2550 Shimadzu, with a $1 \mathrm{~cm}$ optical path length quartz cell, analyses was done in triplicate and absolute ethanol was also used as blank. SPF was calculated by Equation (2), and an assay was made in triplicate.

$$
\mathrm{SPF}=\mathrm{CF} \times \Sigma 320-290 \times \mathrm{EE}(\lambda) \times \mathrm{I}(\lambda) \times \operatorname{ABS}(\lambda)
$$

where,

Equation (2) SPF formula.

$\mathrm{CF}=10$ (correction factor)

$\mathrm{EE}(\lambda)=$ erythematogenic effect

$\mathrm{I}(\lambda)=$ Sun intensity

$\operatorname{ABS}(\lambda)=$ absorbance

\subsection{Statistical Analyses}

The data were obtained in triplicate, calculating the mean, standard error, and relative standard error. The statistical analysis was performed by comparison established through the analysis of variance (ANOVA one way), where the results were considered statistically different when $p<0.05$, the level of significance adopted was $95 \%$ and also the post-test Tukey, using Graphpad Prism 6.01 software, San Diego, CA, USA. The calibration curves and correlation coefficients $(r)$ were obtained and calculated by linear regression using Excel $^{\circledR}$ 2010. Principal component analysis (PCA) was used to obtain the correlation between the different data sets and a more distinct view of the relationship between the variables, as well as the variability of antioxidant activity and SPF. This analysis was performed with the Orange statistics 3.4 program.

\section{Results}

\subsection{Seasonality Effects on Polyphenols, Flavonoids, and RA Content}

In a seasonal analysis of polyphenol content between $M$. villosa and P. amboinicus, statistical difference $(p<0.05)$ was found between the two species in every month of the year, except in August, November, and December, as shown in Figure 1. The best month for M. villosa harvest producing the highest total polyphenols content was September (147 mg GAE/g of crude extract). In P. amboinicus case, it was observed that the best month for its harvest was July (164.7 mg GAE/g of crude extract).

When the two species were evaluated individually, it was possible to observe that there was no statistical difference in total polyphenols content in several months of different seasons of the year in both $M$. villosa and P. amboinicus, showing that their production does not obey a specific trend for each season, e.g., January, which belongs to summer season did not show statistical difference $(p>0.05)$ when compared to April (autumn), August (winter), or October (spring). Thus, these results added to the fact that there are no well-defined seasons at the region where plants were collected, justified by their geographical location close to the equator line, seasons seem to have less influence in the variation of these metabolites concentration. Similar results were observed in a study by Woźniak et al. [47], where the concentrations of most polyphenols remained constant during different seasons, showing that they did not influence the variation of these metabolites. 


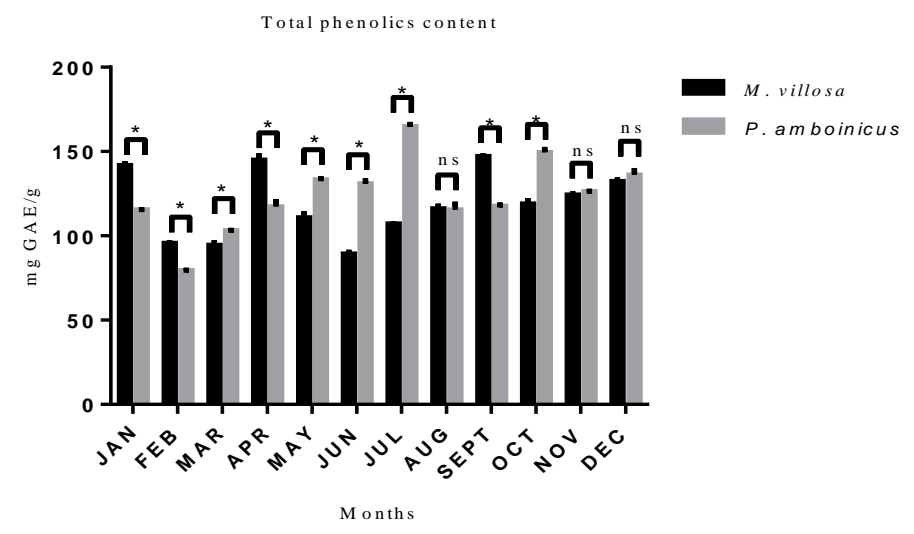

Figure 1. Polyphenols content of M. villosa and P. amboinicus throughout 12 months and their statistical differences. $\mathrm{ns}=$ nonsignificant. ${ }^{*}$ statistical difference.

In the evaluation of flavonoids content, statistical difference $(p<0.05)$ was found among every month of the year between M. villosa and P. amboinicus, as shown in Figure 2. It was also observed that $P$. amboinicus presented the highest values of these metabolites during the whole year, when compared to the other studied species. The best month for M. villosa harvest was April (28.72 mg querc/g of crude extract) and for P. amboinicus, December (49.82 mg querc/g of crude extract).

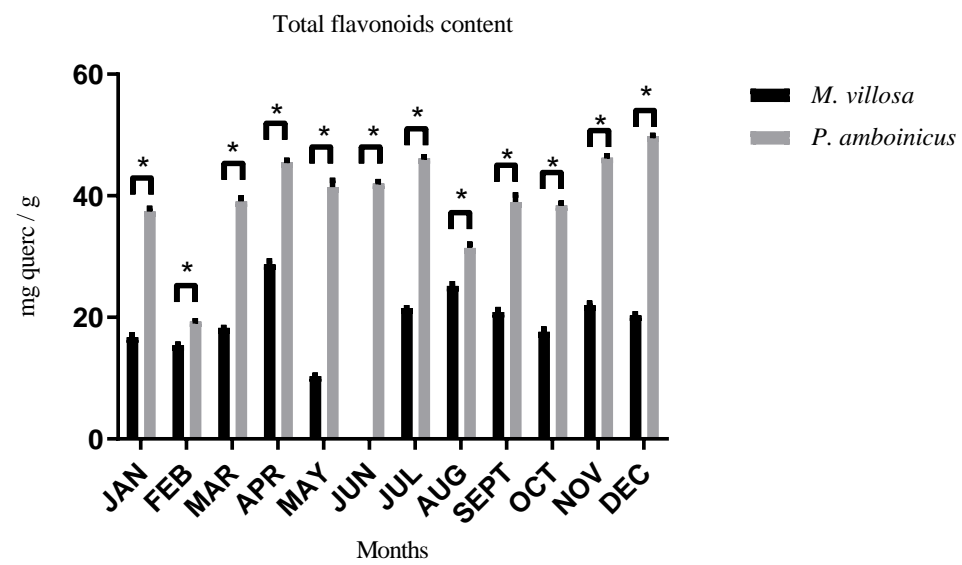

Figure 2. Flavonoids content of M. villosa and P. amboinicus throughout 12 months and their statistical differences. * statistical difference.

As observed for total polyphenols content, when the two species are evaluated individually, it was seen that there was no statistical difference of flavonoids concentration in several months of different seasons in M. villosa and P. amboinicus, indicating that their production also did not obey a specific trend to each season, which shows that seasons seem to have less influence in variation of flavonoids quantitatively production.

According to a previous study by Terto et al. [40] and unpublished data [41], it was seen that RA was the most produced compound in CEE of aerial parts of M. villosa and P. amboinicus, and so because of this, its variation was also evaluated. Thus, it was observed that $P$. amboinicus had the highest concentrations of this metabolite in a good part of the year and the only month that there was no statistical difference in RA content between the two species was August, when they showed statistically equal production, as shown in Figure 3. The best month for M. villosa harvest was September $(39.28 \mathrm{mg} / \mathrm{g})$ and to P. amboinicus, it was observed that in six months of the year, RA concentrations remained practically constant, and it did not show statistical difference among them. These months were January, May, June, July, October, November, and December. Absolute values ranged from 39.46 to $44.24 \mathrm{mg} / \mathrm{g}$, tables containing values of polyphenols, flavonoids and RA content of all months can be found in Supplementary Material. 


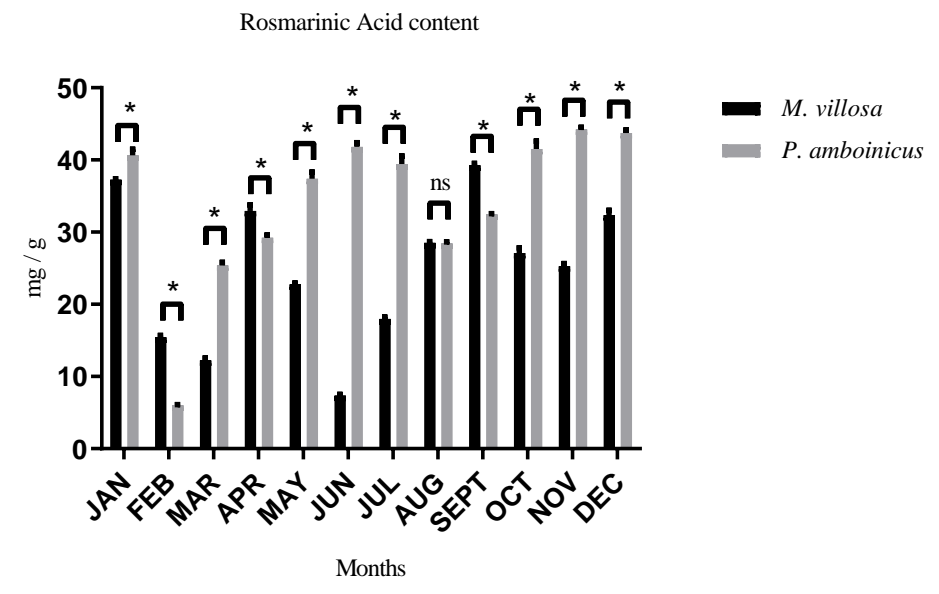

Figure 3. RA content of $M$. villosa and P. amboinicus extracts throughout 12 months and their statistical differences. $\mathrm{ns}=$ nonsignificant. ${ }^{*}$ statistical difference.

As observed to polyphenols and flavonoids content, when the two plants are evaluated individually, no statistical difference was found in RA concentrations in several months of different seasons of the year, indicating that seasons seem to have less influence on RA content variation in both species, although P. amboinicus has shown to be more stable in this metabolite production.

Thus, according to obtained results, it is possible to observe that other factors may have a better influence on the production of polyphenols, flavonoids and RA than only seasons of the year, and it was possible to conclude that the best month to harvest $M$. villosa is September and July for P. amboinicus.

\subsection{Seasonality Effects on Antioxidant Activity}

Samples antioxidant activities were evaluated by DPPH test, and results were expressed as $\mathrm{EC}_{50}$. From Figure 4, a statistical difference is seen among all months, except

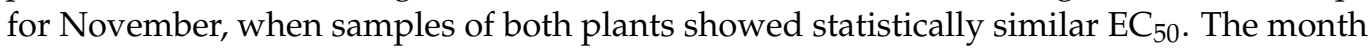
in which $M$. villosa extract showed better action against DPPH radicals is December $(75.09 \mu \mathrm{g} / \mathrm{mL})$ and for P. amboinicus is October $(85.04 \mu \mathrm{g} / \mathrm{mL})$, other results can be found in Supplementary Material.

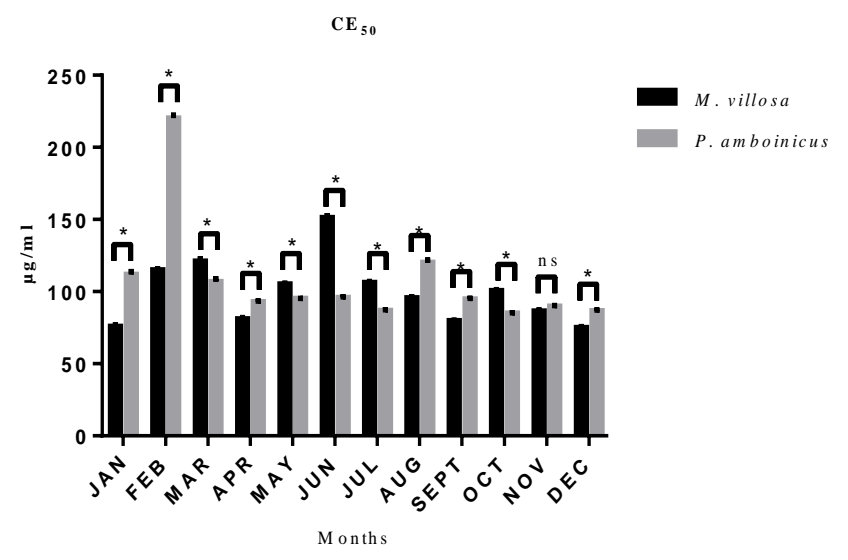

Figure 4. CEE of M. villosa and P. amboinicus $\mathrm{EC}_{50}$ in $\mu \mathrm{g} / \mathrm{mL}$ and their statistical comparations throughout 12 months. ns = nonsignificant. ${ }^{*}$ statistical difference.

\subsection{Seasonality Effects on SPF}

From Figure 5, it was possible to evaluate monthly variations occurred on SPF. It was observed that January, February and December did not presented statistical difference between the two species, while in the rest of the year, this difference is significant. The best month for M. villosa harvest aiming the highest value of SPF was September (SPF = 13.73). 
Regarding P. amboinicus, it was observed that April, May, June and July showed the best values of SPF, what may indicate that autumn favors photoprotective activity of this plant, and SPF reaches its maximum of 14.79, other results can also be found in Supplementary Material.

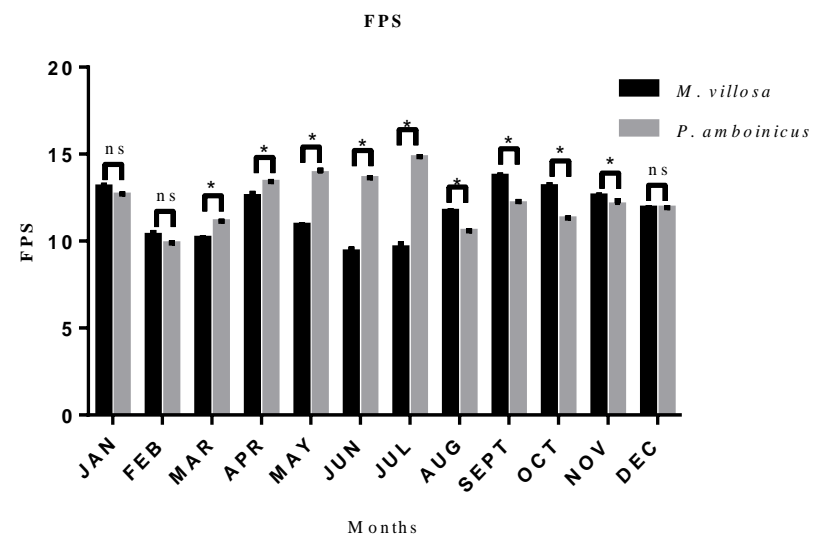

Figure 5. SPF of CEE of M. villosa and P. amboinicus and their statistical comparations throughout 12 months. ns = nonsignificant. * statistical difference.

When is considered that in this test were only used plant extracts of the two studied species incorporated at $10 \%$ in Polawax ${ }^{\circledR}$ cream, it is possible to suggest that these results are promising in the photoprotection area, since reaching SPF levels close to 15 without the addition of any synthetic sunscreen is not easy, as shows the study made by Oliveira et al. [48], that evaluated the SPF of Schinus terebinthifolius Raddi ethanolic extracts and none formulation composed only but extracts had SPF above 5.08. In another study made by Mota et al. [49], it was evaluated SPF of Psidium guajava ethanolic extract and they found SPF = 1. Similarly, Mota et al. [50] evaluated SPF of Nephelium lappaceum L. ethanolic extract (peels) and its $\mathrm{SPF}=0.4$.

Thus, the two studied plants show significant values of SPF throughout the year, which are higher than what is required by the Brazilian Regulatory Agency (ANVISA) in its Resolution of the Collegiate Board of Directors of June, the 30th (2012) [51], that determines that only photoprotective formulations with SPF $\geq 6$ are valid.

\subsection{Principal Components Analysis (PCA)}

To assess the relationship among all existing variables, multivariate analysis of main components was used, which made it possible to observe several correlations between the concentration of RA, phenolic and total flavonoid content, SPF and $\mathrm{EC}_{50}$, as well as the relationship of these variables with the rainfall index and solar radiation during the year.

As shown in Figure 6, the correlation between PC $4 \times$ PC1 of the PCA explained $80 \%$ of the existing groups. For a better understanding of the results, SPF values were categorized through colors to differentiate the value of this parameter in each species. In this figure, it is possible to observe that samples that showed the highest SPF values were grouped more to the left in green, for both M. villosa and P. amboinicus, in addition, it is possible to observe that something beyond the SPF influence in these groups and it is the phenolic content.

According to the linear projection in four axes represented in Figure 7, it is possible to observe blue and red circles, that represents $M$. villosa (MV) and P. amboinicus (PA), respectively. Larger and smaller circles represent higher or lower SPF values. Thus, it is seen that the greater the amount of phenolics and flavonoids, the greater the diameter of the blue circles and, consequently, the greater the SPF of M. villosa extracts. It is also observed that RA presence favors a lower $\mathrm{EC}_{50}$, indicating better antioxidant activity, when it occurs. 


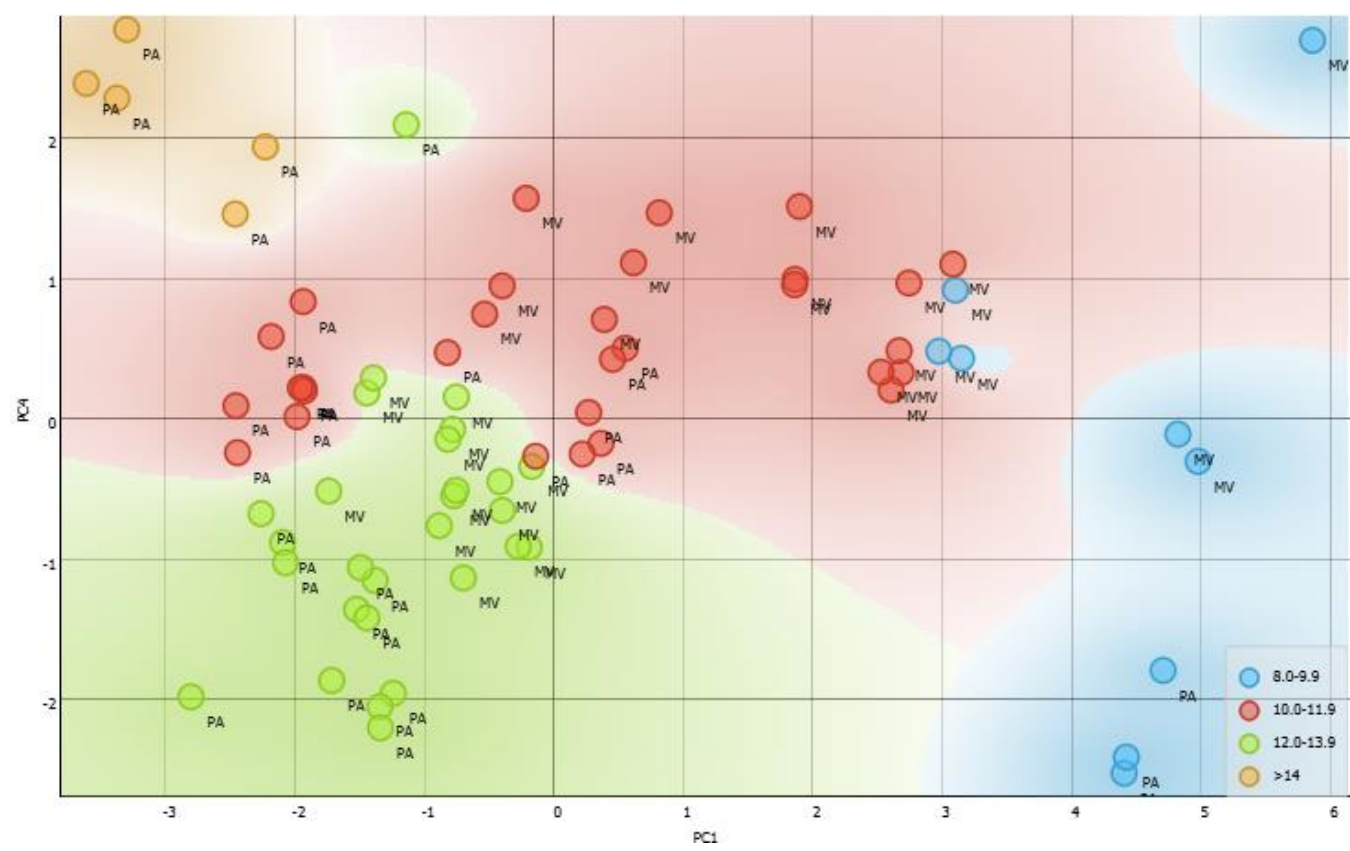

Figure 6. Principal components analysis showing correlation of groups of PC4 versus PC1 using obtained data from the analysis of phenolic and total flavonoid content, RA content, $\mathrm{EC}_{50}, \mathrm{SPF}$, the incidence of solar radiation, and level of precipitation.

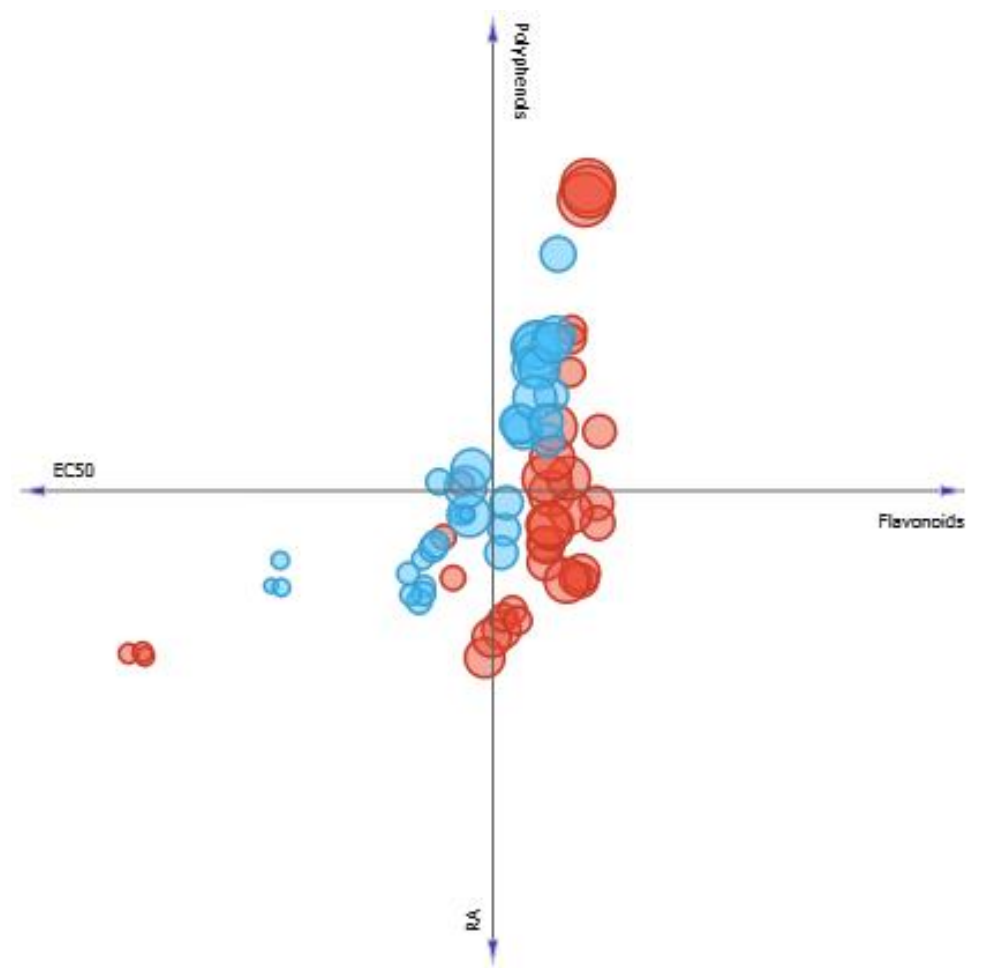

Figure 7. Four axes linear projection correlating the content of phenolics, flavonoids, rosmarinic acid, $\mathrm{EC}_{50}$ of $\mathrm{M}$. villosa (blue circles) and P. amboinicus (red circles). Circles size correspond to a greater or lesser SPF value found.

When it comes to P. amboinicus, in general, it is seen that flavonoids and RA presence keep SPF values similar and low polyphenols concentrations do not favor this factor as much, however, when they reach the maximum concentration found in the species, the highest SPF (14.79) value observed in the present study was found. 
Another parameter observed was the influence of the solar radiation on the concentration of studied secondary metabolites and its consequences to SPF. Thus, evaluating the linear projection presented in Figure 8, it is seen that the solar radiation has great influence on increasing or decreasing SPF in M. villosa. In months when both solar radiation and polyphenols production are higher, SPF of M. villosa extracts increases. However, in months when production of flavonoids and RA is high, but the level of solar radiation is lower, SPF is also lower, suggesting that production of specific components with photoprotective properties is stimulated by solar radiation.

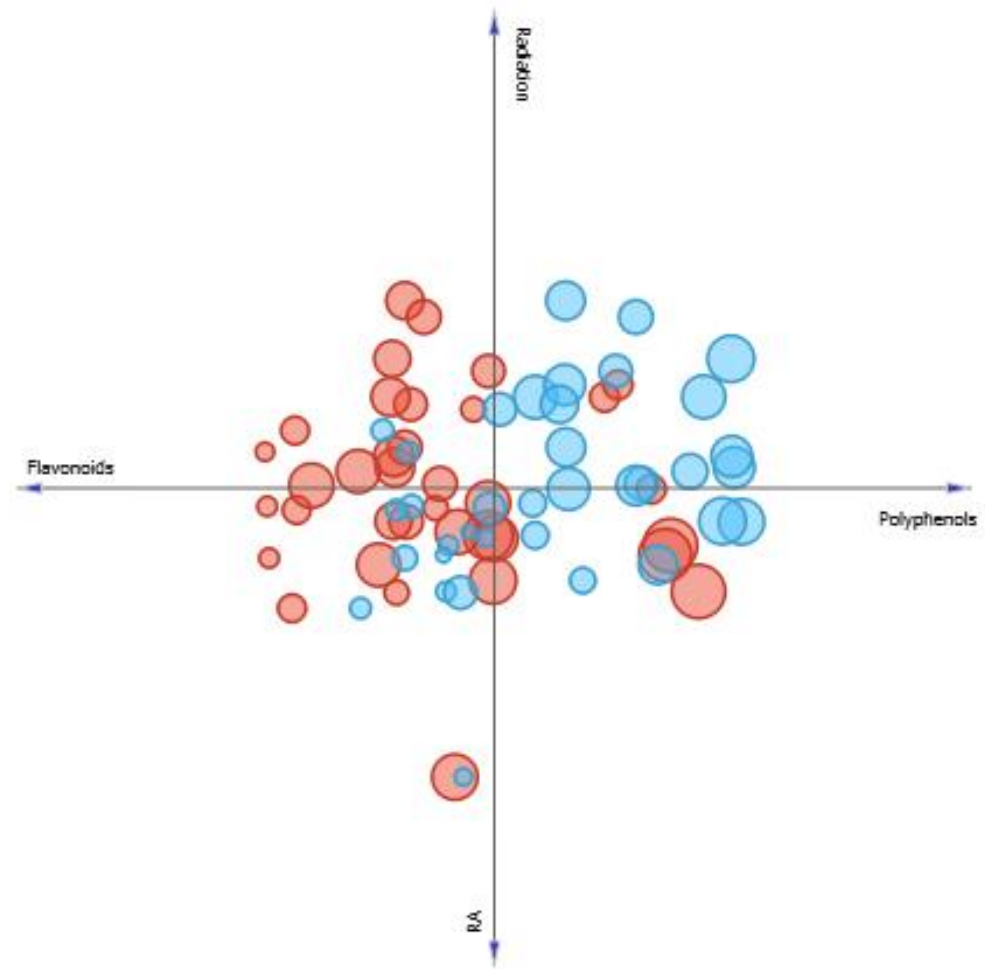

Figure 8. Linear projection correlating the content of phenolics, flavonoids and rosmarinic acid of M. villosa (blue circles) and P. amboinicus (red circles) to solar radiation. Circles size correspond to a greater or lesser SPF value found.

These results are corroborated by Dolzhenko et al. [52], who evaluated the influence of UVB radiation on polyphenols production in Mentha x piperita L. species. In their study, it was seen that polyphenols content increased after irradiation of the plant with UVB radiation, and it stimulated the production of flavonoids with light-absorbing properties at the wavelength corresponding to UVB radiation, such as eriocitrin, hesperidin, and kaempferol 7-O-rutinoside, and it also caused production decrease of narirutin, $4^{\prime}$-methoxykaempferol 7-O-rutinoside, suggesting a possible transformation of these latest flavonoids cited in those with increased production. The same study also showed that there is a decrease in essential oils production in M. piperita and an increase on polyphenols production and suggests a correlation between these results, showing that UVB radiation may favor one biosynthetic path over another.

In P. amboinicus samples, different observations were made. Through Figure 8, it is seen that the solar radiation does not seem to have an influence as directed as in M. villosa, because although SPF was high in samples when solar radiation was higher compared to others, the same observation was made when RA and flavonoids concentrations are higher, and the sample with the highest SPF is found when polyphenols content is higher, but radiation level is lower.

In a study by Takshak et al. [53], it was seen that supplementation of UVB radiation in Coleus forskohlii (or P. barbatus) favored phenylpropanoid paths generating production 
of flavonoids, for example. On the other hand, it was seen on the same study, that UVB radiation also induced an increase of carotenoids production in the leaves of this species, such as lycopene and $\beta$-carotene for its protection. So, although it is necessary more studies to confirm UV radiation role in secondary metabolites production in P. amboinicus, it is possible to suggest that another biosynthetic path may be favored to increase its SPF.

On the other hand, it is seen in Figure 9, that radiation is an important factor in P. amboinicus antioxidant activity since it is showed that when solar radiation levels are higher, $\mathrm{EC}_{50}$ (represented by sample circles size) decreases, which means a better antioxidant activity. This result is corroborated with both Takshak et al. [53] and Takshak et al. [54] that showed an increase of antioxidant activity of Coleus forskohlii extracts when it was supplemented by UVB radiation. A similar result was observed to M. villosa through Figure 9 .

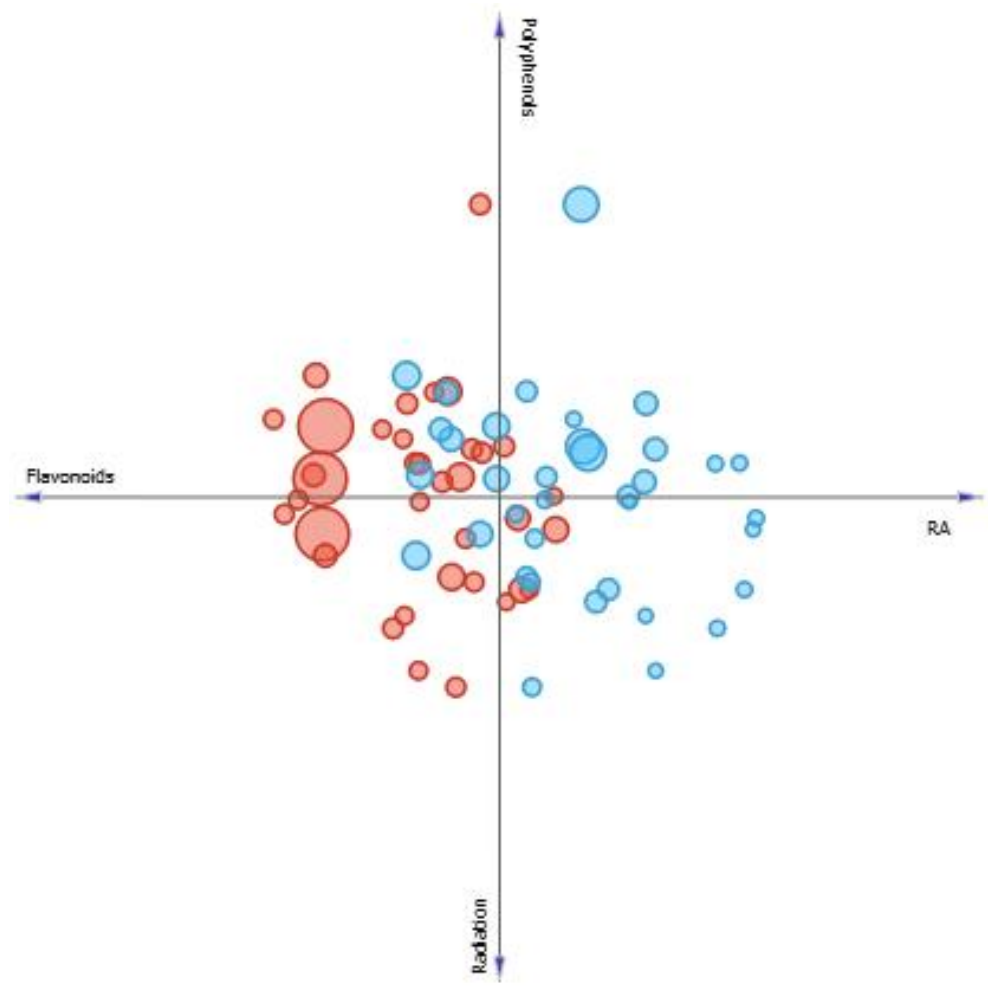

Figure 9. Linear projection correlating the content of phenolics, flavonoids, and rosmarinic acid of M. villosa (blue circles) and P. amboinicus (red circles) to solar radiation. Circles size corresponds to a greater or lesser $\mathrm{EC}_{50}$ value found.

In addition, it is also important to highlight that as seen in a review made by Gobboneto and Lopes [8], certain polyphenols may have their production increased, as in the case of Marchantia polymorpha in which the proportion of luteolin glycosides/apigenin glycosides increases by the influence of exposure to UVB radiation. In this situation, although the absorption capacity of UVB rays does not increase, because luteolin derivates are more efficient in disperse observed energy, it causes an increase of defense antioxidant levels in the plant. The same observation was made in the flavonoids/hydroxycinnamates ratio, with an increase in this proportion being seen by induction of UVB radiation. So, it is seen that the ability to act as an antioxidant and not only as an absorber of UVB radiation, it is important to define which metabolites will be produced to act against UVB rays. Thus, more studies need to be done to better understand the metabolic changes mainly in P. amboinicus.

In the case of precipitation levels, it was observed in Figure 10, that in general, it does not favor both SPF and antioxidant activity increase (Figure 11) of extracts of both plants studied, since the lower precipitation levels, the higher SPF and lower $\mathrm{EC}_{50}$, indicating a better antioxidant activity. 


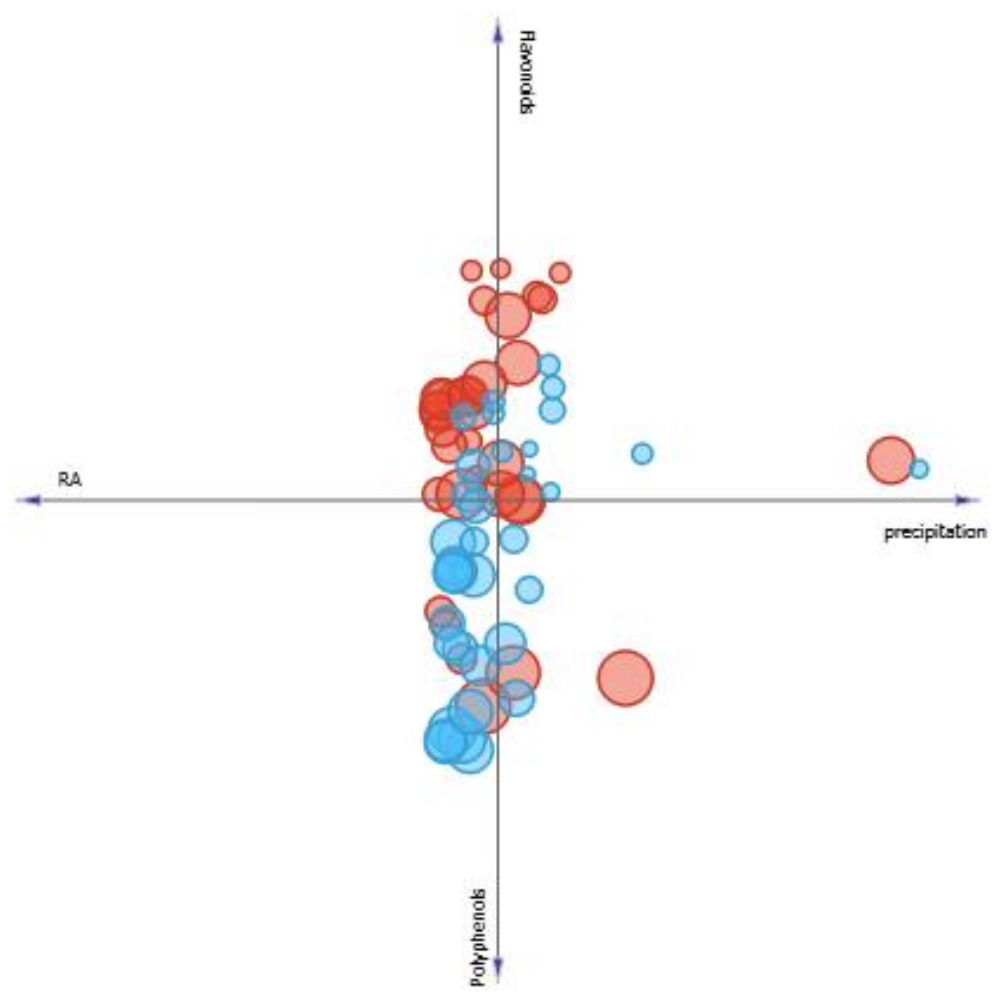

Figure 10. Linear projection correlating the content of phenolics, flavonoids, and rosmarinic acid of M. villosa (blue circles) and P. amboinicus (red circles) to precipitation. Circles size correspond to a greater or lesser SPF value found.

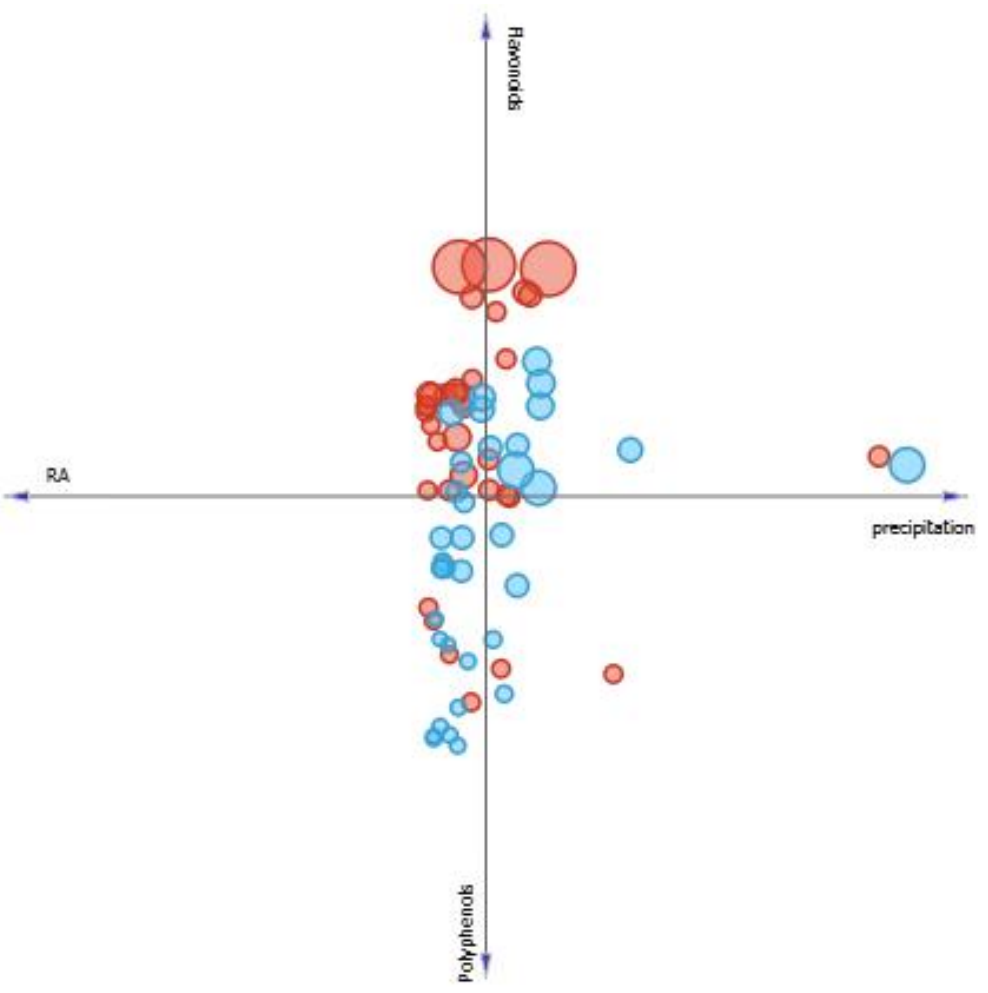

Figure 11. Linear projection correlating the content of phenolics, flavonoids, and rosmarinic acid of M. villosa (blue circles) and P. amboinicus (red circles) to precipitation. Circles size corresponds to a greater or lesser $\mathrm{EC}_{50}$ value found. 
According to Gobbo-neto and Lopes [8], there are controversies about what can occur in polyphenol production depending on environmental levels of precipitation, showing that its production can be increased or decreased, with no trend or pattern to be followed, suggesting that there is no clear correlation between these metabolites concentrations and hydric stress, but short periods of dryness can lead to an increase of phenolic compounds production. Studies such as Gomes et al. [55] showed a predominance of flavonoids during summer in Lippia alba leaves. A similar result was found by Ribeiro et al. [1], where it was found that the highest concentration of total phenolic compounds in the inner bark of Secondatia floribunda A. DC. during the dry season.

Thus, biological activities such as antioxidant activity can be affected since several studies confirm a direct correlation between this activity with phenolic compounds. Because of that, more studies are necessary to establish a better knowledge about what occurs in M. villosa and P. amboinicus metabolism.

\section{Conclusions}

In agreement with all obtained results, it was possible to conclude that, in general, seasonality did not directly affect polyphenols, flavonoids, and RA quantitative production in both species. The best month to harvest $M$. villosa was September and P. amboinicus was July. It could also be concluded that higher concentrations of polyphenols and flavonoids favor the increase of SPF in M. villosa and concentration of RA influences the antioxidant activity of this species, while in P. amboinius, the presence of flavonoids and RA maintained SPF values similar and when the phenolic compounds reached the maximum concentration in this species, the highest SPF value of the study was found (SPF $=14.79)$. Moreover, it was observed that solar radiation has a clearer influence in phenolic compound production and in the increase of SPF in M. villosa than in P. amboinicus, and it favors the improvement of antioxidant activities of both species. In the case of precipitation, it does not seem to favor either photoprotective or antioxidant activities of both species studied.

Supplementary Materials: The following are available online at https:/ / www.mdpi.com/1999-492 3/13/1/110/s1, Figure S1: Calibration curve of Quercetin, Figure S2: Calibration curve of Gallic acid standard, Figure S3: Rosmarinic acid stardand linear regression for its quantification in M. $x$ villosa and P. amboinicus, Figure S4: Superimposed chromatograms of rosmarinic acid triplicate (retention times at $18.24 ; 17.65 ; 17.69 \mathrm{~min}$ ) for its quantification in January, Mentha x villosa, Figure S5: Superimposed chromatograms of rosmarinic acid triplicate (retention times approx-imately at $17.60 \mathrm{~min}$ ) for its quantification in February, Mentha x villosa, Figure S6: Superimposed chromatograms of rosmarinic acid triplicate (retention times approx-imately at $17.60 \mathrm{~min}$ ) for its quantification in March, Mentha $x$ villosa, Figure S7: Superimposed chromatograms of rosmarinic acid triplicate (retention times at $17.65 ; 17.53 ; 17.52 \mathrm{~min}$ ) for its quantification in April, Mentha x villosa, Figure S8: Superimposed chromatograms of rosmarinic acid triplicate (retention times approx-imately at $17.60 \mathrm{~min}$ ) for its quantification in May, Mentha x villosa, Figure S9: Superimposed chromatograms of rosmarinic acid triplicate (retention times approx-imately at $17.53 \mathrm{~min}$ ) for its quantification in June, Mentha $x$ villosa, Figure S10: Superimposed chromatograms of rosmarinic acid triplicate (retention times approx-imately at $17.60 \mathrm{~min}$ ) for its quantification in July, Mentha $x$ villosa, Figure S11: Superimposed chromatograms of rosmarinic acid triplicate (retention times approximately at $17.60 \mathrm{~min}$ ) for its quantification in August, Mentha x villosa, Figure S12: Superimposed chromatograms of rosmarinic acid triplicate (retention times approx-imately at $17.60 \mathrm{~min}$ ) for its quantification in September, Mentha $x$ villosa, Figure S13: Superimposed chromatograms of rosmarinic acid triplicate (retention times approx-imately at $17.63 \mathrm{~min}$ ) for its quantification in October, Mentha $x$ villosa, Figure S14: Superimposed chromatograms of rosmarinic acid triplicate (retention times approx-imately at $17.72 \mathrm{~min}$ ) for its quantification in November, Mentha x villosa, Figure S15: Superimposed chromatograms of rosmarinic acid triplicate (retention times at 17.72; 17.71; $17.92 \mathrm{~min}$ ) for its quantification in December, Mentha $x$ villosa, Figure S16: Superimposed chromatograms of rosmarinic acid triplicate (retention times at $10.07 ; 9.54 ; 10.07 \mathrm{~min}$ ) for its quantification in January, Pectranthus amboinicus, Figure S17: Superimposed chromatograms of rosmarinic acid triplicate (retention times approx-imately at $10.14 \mathrm{~min}$ ) for its quantification in February, Pectranthus amboinicus, Figure S18: Superimposed chromatograms of rosmarinic acid triplicate (retention times approx-imately at $9.55 \mathrm{~min}$ ) for its quantification in March, 
Pectranthus amboinicus, Figure S19: Superimposed chromatograms of rosmarinic acid triplicate (retention times approx-imately at $9.56 \mathrm{~min}$ ) for its quantification in April, Pectranthus amboinicus, Figure S20: Superimposed chromatograms of rosmarinic acid triplicate (retention times approximately at $9.57 \mathrm{~min}$ ) for its quantification in June, Pectranthus amboinicus, Figure S21: Superimposed chromatograms of rosmarinic acid triplicate (retention times at 9.60; 9.62; $10.15 \mathrm{~min}$ ) for its quantification in July, Pectranthus amboinicus, Figure S22: Superimposed chromatograms of rosmarinic acid triplicate (retention times approx-imately at $10.14 \mathrm{~min}$ ) for its quantification in August, Pectranthus amboinicus, Figure S23: Superimposed chromatograms of rosmarinic acid triplicate (retention times at $9.64 ; 10.19 ; 10.19 \mathrm{~min}$ ) for its quantification in October, Pectranthus amboinicus, Figure S24: Superimposed chromatograms of rosmarinic acid triplicate (retention times at 10.05; 9.64; $9.61 \mathrm{~min}$ ) for its quantification in November, Pectranthus amboinicus, Figure S25: Superimposed chromatograms of rosmarinic acid triplicate (retention times approx-imately at $9.65 \mathrm{~min}$ ) for its quantification in December, Pectranthus amboinicus, Table S1: Results of month-to-month quantification of rosmarinic acid in $\mathrm{mg} / \mathrm{g}$, Mentha $x$ villosa, Table S2: Results of month-to-month quantification of rosmarinic acid in $\mathrm{mg} / \mathrm{g}$, Plectranthus amboinicus, Table S3: SPF results month by month, Mentha $x$ villosa, Table S4: SPF results month by month, Plectranthus amboinicus, Table S5: Results of total phenolic content month by month mg GAE/ g, Mentha $x$ villosa, Table S6: Results of the total phenolic content month by month mg GAE/g, Plectranthus am-boinicus, Table S7: Results of total flavonoid content month by month mg querc/g, Mentha $x$ villosa, Table S8: Results of total flavonoid content month by month mg querc/ g, Plectranthus amboinicus, Table S9: Radiation data used $\left(\mathrm{kJ} / \mathrm{m}^{2}\right)$, Table S10. Precipitation levels used $\left(\mathrm{mm}^{3}\right)$.

Author Contributions: J.d.M.G. and M.V.C.T. were responsible for collecting plant material, producing plant extracts, photoprotection assay, rosmarinic acid quantification by HPLC, determining phenolic and flavonoid total content, and interpretation of results. S.G.d.S. contributed to the interpretation of data, software usage, and graphics production. J.F.T. and M.S.d.S. were responsible for coordinating the project, funding acquisition, interpretation of results, and antioxidant assay. All authors have read and agreed to the published version of the manuscript.

Funding: This research was funded by the National Institutes of Science and Technology Program (INCT-Rennofito, $\left.n^{\circ} 465536 / 2014-0\right), C N P q\left(n^{\circ} 141383 / 2018-6\right.$ and $\left.n^{\circ} 141208 / 2016-3\right)$ and CAPES code 001 .

Institutional Review Board Statement: Not applicable.

Informed Consent Statement: Not applicable.

Data Availability Statement: The data presented in this study are available in Supplementary Material.

Acknowledgments: Authors would like to acknowledge Genuspharma ${ }^{\circledR}$ pharmacy for providing materials for this work and their facilities, so cosmetic formulations could be produced. We also thank Tainá Souza Silva and Jarllys Nóbrega de Souza for helping us with a few analyses made.

Conflicts of Interest: The authors declare no conflict of interest.

\section{References}

1. Ribeiro, D.A.; Camilo, C.J.; Nonato, C.F.A.; Rodrigues, F.F.G.; Menezes, I.R.A.; Ribeiro-filho, J.; Xiao, J.; Souza, M.M.A.; Costa, J.G.M. Influence of seasonal variation on phenolic content andin vitro anti-oxidant activity of Secondatia floribunda A. DC. (Apocynaceae). Food Chem. 2020, 315, 126277. [CrossRef] [PubMed]

2. Karimi, A.; Krähmer, A.; Herwig, N.; Hadian, J.; Schulz, H.; Meiners, T. Metabolomics Approaches for Analyzing Effects of Geographic and Environmental Factors on the Variation of Root Essential Oils of Ferula assa-foetida L. J. Agric. Food Chem. 2020, 68, 9940-9952. [CrossRef] [PubMed]

3. Beer, D.; Miller, N.; Joubert, E. Production of dihydrochalcone-rich green rooibos (Aspalathus linearis) extract taking into account seasonal and batch-to-batch variation in phenolic composition of plant mate-rial. S. Afr. J. Bot. 2017, 110, 138-143. [CrossRef]

4. Lemos, M.F.; Lemos, M.F.; Pacheco, H.P.; Guimarães, A.C.; Fronza, M.; Endringer, D.C.; Scherer, R. Seasonal variation affects the composition and antibacterial and antioxidant activities of Thymus vulgaris. Ind. Crop. Prod. 2017, 95, 543-548. [CrossRef]

5. Nenadis, N.; Llorens, L.; Koufogianni, A.; Díaz, L.; Font, J.; Gonzalez, J.A.; Verdaguer, D. Interactive effects of UV radiation and reduced precipitation on the seasonal leaf phenolic content/composition and the antioxidant activity of naturally growing Arbutus unedo plants. J. Photochem. Photobiol. B Biol. 2015, 153, 435-444. [CrossRef]

6. Bundy, J.G.; Davey, M.P.; Viant, M.R. Environmental metabolomics: A critical review and future perspectives. Metabolomics 2009, 5, 3-21. [CrossRef] 
7. Ferraz, E.D.O.; Vieira, M.A.R.; Ferreira, M.I.; Junior, A.F.; Marques, M.O.M.; Minatel, I.O.; Albano, M.; Sambo, P.; Lima, G.P.P. Seasonality effects on chemical composition, antibacterial activity and essential oil yield of three species of Nectandra. PLOS ONE 2018, 13, e0204132. [CrossRef]

8. Gobbo-neto, L.; Lopes, N.P. Plantas medicinais: Fatores de influência no conteúdo de metabólitos secundários. Quim. Nova 2007, 30, 374-381. [CrossRef]

9. Matos, F.J.A. Farmácias Vivas; Edicões UFC: Fortaleza, Brazil, 2001.

10. Matos-Rocha, T.; Cavalcanti, M.D.S.; Barbosa-Filho, J.; Lúcio, A.; Veras, D.; Feitosa, A.; Júnior, J.D.S.; De Almeida, R.; Marques, M.O.M.; Alves, L.; et al. In Vitro Evaluation of Schistosomicidal Activity of Essential Oil of Mentha $x$ villosa and Some of Its Chemical Constituents in Adult Worms of Schistosoma mansoni. Planta Med. 2013, 79, 1307-1312. [CrossRef]

11. Guedes, D.N.; Silva, D.; Barbosa-Filho, J.; Medeiros, I.A. Endothelium-dependent hypotensive and vasorelaxant effects of the essential oil from aerial parts of Mentha $x$ villosa in rats. Phytomedicine 2004, 11, 490-497. [CrossRef]

12. Sousa, P.J.C.; Linard, C.F.B.M.; Azevedo-Batista, D.; Oliveira, A.C.; Coelho-de-Souza, A.N.; Leal-Cardoso, J.H. Antinociceptive effects of the essential oil of Mentha xvillosa leaf and its major constit-uent piperitenone oxide in mice. Braz. J. Med. Biol. Res. 2009, 42, 655-659. [CrossRef] [PubMed]

13. Amaral, R.G.; Fonseca, C.S.; Silva, T.K.M.; Andrade, L.N.; França, M.E.; Barbosa-Filho, J.M.; Sousa, D.P.; Morares, M.O.; Pessoa, C.Ó.; Carvalho, A.A.; et al. Evaluation of the cytotoxic and antitumour effects of the essential oil from Mentha $x$ villosa and its main compound, rotundifolone. J. Pharm. Pharmacol. 2015, 67, 1100-1106. [CrossRef] [PubMed]

14. Shen, D.; Pan, M.-H.; Wu, Q.; Park, C.-H.; Juliani, H.R.; Ho, C.-T.; Simon, J.E. A Rapid LC/MS/MS Method for the Analysis of Nonvolatile Antiinflammatory Agents from Mentha spp. J. Food Sci. 2011, 76, C900-C908. [CrossRef] [PubMed]

15. Brahmi, F.; Khodir, M.; Mohamed, C.; Pierre, D. Chemical Compostion and Biological Activities of Men-tha Species. In Aromatic and Medicinal Plants-Back to Nature; El-Shemy, H.A., Ed.; InTech: Rijeka, Croatia, 2017; pp. 47-80.

16. Hanafy, D.M.; Prenzler, P.D.; Burrows, G.E.; Ryan, D.; Nielsen, S.; Sawi, S.A.E.; Alfy, T.S.E.; Ab-delrahman, E.H.; Obied, H.K. Biophenols of mints: Antioxidant, acetylcholinesterase, butyrylcholines-terase and histone deacetylase inhibition activities targeting Alzheimer's disease treatment. J. Funct. Foods 2017, 33, 345-362. [CrossRef]

17. Hsu, K.-P.; Ho, C.-L. Antimildew Effects of Plectranthus amboinicus Leaf Essential Oil on Paper. Nat. Prod. Commun. 2019, 14. [CrossRef]

18. Manjamalai, A.; Alexander, T.; Berlin Grace, V.M. Bioactive evaluation of the essential oil of plectran-thus amboinicus by gc-ms analysis and its role as a drug for microbial infections and inflammation. Int. J. Pharm. Pharm. Sci. 2012, 4, $205-211$.

19. Shubha, J.; Bhatt, P. Plectranthus amboinicus leaves stimulate growth of probiotic L. plantarum: Evidence for ethnobotanical use in diarrhea. J. Ethnopharmacol. 2015, 166, 220-227. [CrossRef]

20. Gurgel, A.P.A.D.; Da Silva, J.G.; Grangeiro, A.R.S.; Oliveira, D.C.; Lima, C.M.; Da Silva, A.C.; Oliveira, R.A.; Souza, I.A. In vivo study of the anti-inflammatory and antitumor activities of leaves from Plectranthus amboinicus (Lour.) Spreng (Lamiaceae). J. Ethnopharmacol. 2009, 125, 361-363. [CrossRef]

21. Oliveira, R.A.G.; Lima, E.O.; Vieira, W.L.; Freire, K.R.L.; Trajano, V.N.; Lima, I.O.; Souza, E.L.; Toledo, M.S.; Silva-Filho, R.N Estudo da interferência de óleos essenciais sobre a atividade de alguns antibióticos usados na clínica. Rev. Bras. Farmacogn. 2006, 16, 77-82. [CrossRef]

22. Yulianto, W.; Andarwulan, N.; Giriwono, P.E.; Pamungkas, J. Bioactive compounds from torbangun (plectranthus amboinicus (lour.) spreng) chlo-roform fraction induce apoptosis in breast cancer (mcf-7 cells) in vitro. Tradit. Med. J. 2017, $22,37-44$. [CrossRef]

23. Gurgel, A.P.A.D.; da Silva, J.G.; Grangeiro, A.R.S.; Xavier, H.S. Antibacterial Effects of Plectranthus amboinicus (Lour.) Spreng (Lamiaceae) in Methicillin Resistant Staphylococcus aureus (MRSA). Lat. Am. J. Pharm. 2009, 28, 460-464.

24. Olszewska, M.A.; Gędas, A.; SImões, M. Antimicrobial polyphenol-rich extracts: Applications and limi-tations in the food industry. Food Res. Int. 2020, 134, 109214. [CrossRef] [PubMed]

25. Kumar, P.; Singh, S.; Kumar, N. Plectranthus amboinicus: A review on its pharmacological and, pharmacognostical studies. Am. J. Physiol. Biochem. Pharmacol. 2020, 10. [CrossRef]

26. Balakrishnan, A. Therapeutic uses of peppermint-A review. J. Pharm. Sci. Res. 2015, 7, 474-476.

27. Lima, T.C.; Silva, T.K.M.; Silva, F.L.; Barbosa-Filho, J.M.; Marques, M.O.M.; Santos, R.L.C.; Caval-canti, S.C.H.; Sousa, D.P. Larvicidal activity ofMenthaxvillosaHudson essential oil, rotundifoloneand derivatives. Chemosphere 2014, 104, 37-43. [CrossRef] [PubMed]

28. Fialova, S.; Veizerova, L.; Nosalova, V.; Drabikova, K.; Tekelova, D.; Grancai, D.; Sotnikova, R. Water Extract of Mentha $x$ villosa: Phenolic Fingerprint and Effect on Ischemia-Reperfusion Injury. Nat. Prod. Commun. 2015, 10, 937-940. [CrossRef]

29. Arumugam, G.; Swamy, M.K.; Sinniah, U.R. Plectranthus amboinicus (Lour.) Spreng: Botanical, Phytochemical, Pharmacological and Nutritional Significance. Molecules 2016, 21, 369. [CrossRef]

30. Dalmagro, A.P.; Camargo, A.; Filho, H.H.D.S.; Valcanaia, M.M.; De Jesus, P.C.; Zeni, A.L.B. Seasonal variation in the antioxidant phytocompounds production from the Morus nigra leaves. Ind. Crop. Prod. 2018, 123, 323-330. [CrossRef]

31. Henriques, A.C.R. Estudo dos Efeitos Antioxidante e Anti-Inflamatório do Chocolate Preto e da Pasta de Cacao; Master's Thesis, Faculdade de Farmácia da Universidade de Coimbra, Coimbra, Portugal, 2017.

32. Ko, H.C.; Lee, J.Y.; Jang, M.G.; Song, H.; Kim, S.-J. Seasonal variations in the phenolic compounds and antioxidant activity of Sasa quelpaertensis. Ind. Crop. Prod. 2018, 122, 506-512. [CrossRef] 
33. Sousa, C.M.D.M.; E Silva, H.R.; Vieira, G.M., Jr.; Ayres, M.C.C.; Da Costa, C.L.S.; Araújo, D.S.; Cavalcante, L.C.; Barros, E.D.S.; Araújo, P.B.D.M.; Brandão, M.S.; et al. Fenóis totais e atividade antioxidante de cinco plantas medicinais. Química Nova 2007, 30, 351-355. [CrossRef]

34. León-chan, R.G.; López-meyer, M.; Osuna-enciso, T.; Sañudo-barajas, A.; Heredia, J.B.; León-félix, J. Low temperature and ultraviolet-B radiation affect chlorophyll content and induce the accumulation of UV-B-absorbing and antioxidant compounds in bell pepper (Capsicum annuum) plants. Environ. Exp. Bot. 2017, 139, 143-151. [CrossRef]

35. Takshak, S.; Agrawal, S. Defense potential of secondary metabolites in medicinal plants under UV-B stress. J. Photochem. Photobiol. B Biol. 2019, 193, 51-88. [CrossRef] [PubMed]

36. Amoah, S.K.S.; Sandjo, L.P.; Kratz, J.M.; Biavatti, M.W. Rosmarinic Acid-pharmaceutical and clini-cal aspects. Planta Med. 2016, 82, 388-406. [PubMed]

37. Psotova, J.; Svobodová, A.R.; Kolarova, H.; Walterova, D. Photoprotective properties of Prunella vulgaris and rosmarinic acid on human keratinocytes. J. Photochem. Photobiol. B Biol. 2006, 84, 167-174. [CrossRef] [PubMed]

38. Sánchez-campillo, M.; Gabaldon, J.A.; Castillo, J.; Benavette-garcía, O.; Del bãno, M.J.; Alcaraz, M.; Vicente, V.; Alvarez, N.; Lozano, J.A. Rosmarinic acid, a photoprotective agent agaisnt UV and other ionizing radiations. Food Chem. Toxicol. 2009, 47, 386-392. [CrossRef]

39. Blackman, B.K. Changing Responses to Changing Seasons: Natural Variation in the Plasticity of Flow-ering Time. Plant Physiol. 2017, 173, 16-26. [CrossRef]

40. Terto, M.V.C.; Gomes, J.M.; Araújo, D.I.A.F.; Silva, T.S.; Ferreira, J.M.; Souza, J.J.N.; Da Silva, M.S.; Tavares, J.F. Photoprotective Activity of Plectranthus amboinicus Extracts and HPLC Quantification of Rosmarinic Acid. Rev. Bras. Farm. 2020, 30, 183-188. [CrossRef]

41. GOMES, J.M. Estudo Preliminar da Potencial Atividade Fotoprotetora e Antioxidante de Mentha $x$ villosa, Master's Thesis, Universidade Federal da Paraíba, João Pessoa, Brazil, 2018, unpublished.

42. Singleton, V.L.; Orthofer, R.; Lamuela-Raventós, R.M. Analysis of total phenols content and other oxi-dation substrates and antioxidants by means of Folin-Ciocalteu reagent. Method Enzymol. 1999, 299, 152-177.

43. Schmidt, P.C.; Ortega, G.G. Passionsblumenkraut. Bestimmung des Gesamt flavonoid gehaltes von Passiflorae herba. Dtsch. Apoth. Ztg. 1999, 133, 17-26.

44. Marques, G.S.; Monteiro, R.P.M.; Leão, W.F.; Lyra, M.A.M.; Peixoto, M.S.; Rolim-neto, P.J.; Xavier, H.S.; Soares, L.A.L. Avaliação de procedimentos para quantificação espectrofotométrica de flavonoides totais em folhas de Bauhinia forficata LINK. Quim. Nova 2012, 35, 517-522. [CrossRef]

45. Garcez, F.R.; Garcez, W.S.; Hamerski, L.; Miguita, C.H. Fenilpropanóides e outros constituintes bioativos de Nectandra megapotamica. Quim. Nova 2009, 32, 407-411. [CrossRef]

46. Mansur, J.S.; Breder, M.N.R.; Mansur, M.C.A.; Azulay, R.D. Determinação do fator de proteção solar por espectrofotometria. An. Bras. Dermatol. 1986, 61, 121-124.

47. Woźniak, M.; Mrówczyńska, L.; Waśkiewicz, A.; Rogoziński, T.; Ratajczak, I. The role of seasonality on the chemical composition, antioxidant activity and cytotoxicity of Polish propolis in human erythrocytes. Rev. Bras. Farm. 2019, 29, 301-308. [CrossRef]

48. Oliveira, M.B.; Valentim, I.B.; Rocha, T.S.; Santos, J.C.; Pires, K.S.; Tanabe, E.L.; Borbely, K.S.; Borbely, A.U.; Goulart, M.O.F. Schinus terebenthifolius Raddi extracts: from sunscreen activity toward protection of the placenta to Zika virus infection, new uses for a well-known medicinal plant. Ind. Crop. Prod. 2020, 152, 112503. [CrossRef] [PubMed]

49. Mota, M.D.; Morte, A.N.D.B.; Silva, L.C.R.C.E.; Chinalia, F.A. Sunscreen protection factor enhancement through supplementation with Rambutan (Nephelium lappaceum L.) ethanolic extract. J. Photochem. Photobiol. B Biol. 2020, 205, 111837. [CrossRef] [PubMed]

50. Mota, M.D.; Costa, R.Y.S.; Guedes, A.A.S.; Silva, L.C.R.C.E.; Chinalia, F.A. Guava-fruit extract can improve the UV-protection efficiency of synthetic filters in sun cream formulations. J. Photochem. Photobiol. B Biol. 2019, 201, 111639. [CrossRef]

51. Anvisa. $R D C n^{\circ}$ 30, de 01 de Junho de 2012; Brasil, Ministério da Saúde. Agência Nacional de Vigilância Sanitária (ANVISA), Diário Oficial da União, DF: Brasília, Brazil.

52. Dolzhenko, Y.; Bertea, C.M.; Occhipinti, A.; Bossi, S.; Maffei, M.E. UV-B modulates the interplay be-tween terpenoids and flavonoids in peppermint (Mentha piperita L.). J. Photochem. Photobiol. B Biol. 2010, 100, 67-75. [CrossRef]

53. Takshak, S.; Agrawal, S.B. Interactive effects of supplemental ultraviolet-B radiation and indole-3-acetic acid on Coleus forskohlii Briq.: Alterations in morphological-, physiological-, and biochemical character-istics and essential oil content. Ecotoxicol. Environ. Saf. 2018, 147, 313-326. [CrossRef]

54. Takshak, S.; Agrawal, S. The role of supplemental ultraviolet-B radiation in altering the metabolite profile, essential oil content and composition, and free radical scavenging activities of Coleus forskohlii, an indigenous medicinal plant. Environ. Sci. Pollut. Res. 2015, 23, 7324-7337. [CrossRef]

55. Gomes, A.F.; Almeida, M.P.; Leite, M.F.; Schwaiger, S.; Stuppner, H.; Halabalaki, M.; Amaral, J.G.; David, J.M. Seasonal variation in the chemical composition of two chemotypes of Lippia alba. Food Chem. 2019, 273, 186-193. [CrossRef] 